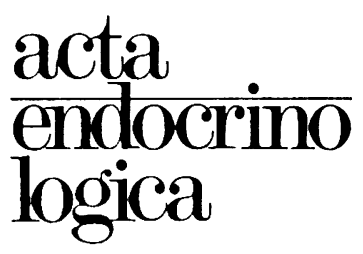

Advances

in Thyroidology

Cell- and Immunobiological Aspects

Proceedings of an International Merck-Symposium organized by the Department of Internal Medicine, Medical University Lübeck and

Deutsche Forschungsgemeinschaft, SFB 232, held in Lübeck, 2nd to 4th October, 1986

EDITORS

B. E. WENZEL

G. F. BOT TAZZO

Supplementum 281

Copenhagen 1987 


\section{List of Contents}

\section{Autoantigen and antigen presentation in autoimmune thyroid disease}

Thyroid cell MHC class II antigens: A perspective on the aetiology of autoimmune thyroid disease ...................... 13

T. F. Davies, S. H. Roman, W. A. Mackenzie,

N. Goldsmith, S. M. Dower and L. A. Piccinini

Modulation of class-II antigen expression in human thyroid epithelial cell cultures ........ 21

B. E. Wenzel, H. Arnholdt, S. Grammerstorf,

R. Gutekunst and P. C. Scriba

Thyrocyte HLA class II expression and regulation in relation to thyroid autoimmunity $\ldots .27$

Ian Todd, Ricardo Pujol-Borrell,

Antonino Belfiore and Gian Franco Bottazzo

Aberrant expression of class II HLA antigens by the target cell: Cause or consequence of the autoimmune aggression? ............. 35

Emilio L. Khoury

Dendritic cells in autoimmune thyroid disease 42

P.J. Kabel, H. A. M. Voorbij,

R. D. van der Gaag, W. M. Wiersinga,

$M$. de Haan and H. A. Drexhage

Thyroid peroxidase is the organ-specific 'microsomal' autoantigen involved in thyroid autoimmunity ...................... 49

Jean Ruf, Barbara Czarnocka,

Catherine De Micco, Catherine Dutoit,

Mireille Ferrand and Pierre Carayon

Cellular localization of the microsomal antigen and the thyroid peroxidase antigen ....... 57

A. Pinchera, S. Mariotti, L. Chiovato, P. Vitti,

G. Lopez, A. Lombardi, S. Anelli, R. Bechi

and P. Carayon

Concept of a multigenic basis for the pathogenesis of spontaneous autoimmune thyroiditis ....6 63 G. Wick
Effect of iodine intake and methimazole on lymphocytic thyroiditis in the $\mathrm{BB} / \mathrm{W}$ rat ....... 70

Lewis E. Braverman, Terri Paul,

Walter Reinhardt, Michael C. Appel

and Elsie M. Allen

Transplantation of human endocrine tissues to nude mice: A suitable in vivo model for the study of pathomechanisms involved in autoimmune thyroid diseases .................. 77

K. H. Usadel, J. Teuber, R. Paschke, M. Junker

and $U$. Schwedes

Thyrocytes can synthesize HLA class II molecules ...................... 82

M. Londei, B. Grubeck-Loebenstein,

M. Kissonerghis, P. Austin, J. Trowsdale,

C. Greenall and M. Feldmann

Comparison of the cellular infiltrate of Hashimoto's thyroiditis in vivo and after in vitro cell growth .................... 86

M. Londei, B. Grubeck-Loebenstein,

C. Greenall, M. Turner and M. Feldmann

Stimulatory activities of antigen presenting cells in mixed leucocyte reactions (MLR) in thyroid diseases ...................... 89

B. Grubeck-Loebenstein, M. Londei,

C. Greenall, K. Pirich, W. Waldhäusl and F. Feldmann

The influence of interleukin-1 on the function of in vitro cultured human thyroid cells in monolayers ....................... 93

Ase Krogh Rasmussen, Karine Bech, Ulla Feldt-Rasmussen, Svenn Poulsen, Kaj Siersbak-Nielsen, Thorkild Friis and K. Bendtzen

Reduced intrathyroidal K-cell activity in Graves' disease ........................ 96

$U$. Bogner and H. Schleusener 
Is remission of Graves' disease regulated by antiidiotypic antibodies? 99

R. Paschke, J. Teuber, U. Schwedes and K. H. Usadel

Induction of experimental autoimmune thyroiditis by a 5-10 Kd peptidic fragment from porcine thyroglobulin ................... 104

\section{J. Salamero, J. A. Boudier, J.J. Rémy}

and J. Charreire

Dysregulation of the immune system in obese strain chickens with Hashimoto-like thyroiditis: Intrinsic and extrinsic mechanisms . ...... 107

K. Schauenstein, R. Fässler, G. Krömer and G. Wick

Characterization of thyroid infiltrating lymphocytes in Hashimoto's thyroiditis. Detection of B and $\mathrm{T}$ cells specific for thyroid antigens .... 111

G. F. Del Prete, S. Mariotti, A. Tiri, M. Ricci,

A. Pinchera and S. Romagnani

Graves' IgG stimulates thyroid epithelial cell proliferation in xenotransplanted human toxic diffuse goitre ................... 115

\section{Erik Jörtsö, Lennart Tegler}

and Staffan Smeds

Thyrotoxic effect of high iodine doses on xenotransplanted autoimmune thyroid tissue in athymic nude mice .................... 118

Petra-Maria Schumm-Draeger, K. H. Usadel,

B. O. Böhm, F.D. Maul, H.J.C. Wenisch,

R. Senekowitsch, C. R. Pickardt

and K. Schöffling

\section{In vitro investigations in autoimmune thyroid disease}

The thyroid microenvironment in autoimmune thyroid disease: Effects of TSH and lymphokines on thyroid lymphocytes and thyroid cells ... 125

S. M. McLachlan, C. A. S. Pegg,

M. C. Atherton, S. L. Middleton, A. Dickinson,

F. Clark and B. Rees Smith

Cellular and antibody mediated cytotoxicity in autoimmune thyroid disease ........... 133

Ulrich Bogner, Jack R. Wall

and Horst Schleusener
Molecular cloning of antigens to thyroid autoantibodies using the expression vector lambda gt $11 \ldots \ldots \ldots \ldots \ldots \ldots \ldots \ldots \ldots . \ldots . \ldots . \ldots . \ldots$

Basil Rapoport, Hideshi Hirayu, Pui Seto and Ronald P. Magnusson

Restriction enzyme analysis of HLA class II DR $\beta$ genes in patients with Graves' disease ..... 146

Bernhard O. Boehm, E. Schifferdecker,

P. Kuehnl, C. Rosak and K. Schöffling

Polymorphism of the immunoglobulin heavy chain $T$ cell receptor $\beta$-chain genes in Graves' disease ........................... 149

A. Demaine, K. I. Welsh, B. S. Hawe

and Nadir R. Farid

An anti-idiotypic antibody against Graves' IgG 152

Beverley S. Hawe and N. R. Farid

\section{The TSH-receptor:}

\section{Structure and function}

The TSH receptor: Structure and interaction with autoantibodies in thyroid disease ..... 157

J. Furmaniak, Y. Nakajima, F. A. Hashim,

F. M. Creagh, E. Davies Jones, R. D. Howells,

S. M. McLachlan and B. Rees Smith

TSH receptor structure ............. 166

John Chan, Pilar Santisteban, Michele De Luca, Osamu Isozaki, Evelyn Grollman

and Leonard Kohn

Characterization of monoclonal antibodies directed against the $\mathrm{TSH}$ receptor, as revealed with the cytochemical bioassay ............. 173

N.J. Marshall, L. D. Kohn and P. A. Ealey

About the porcine TSH receptor ........ 181

Nadir R. Farid

and Goverdina Fahraeus-van Ree

Properties of thyrotropin receptor on cloned hybrid human thyroid cells $\ldots \ldots \ldots \ldots \ldots 186$

\section{Jean-Jacques Rémy, Jean Salamero}

and Jeannine Charreire

Inhomogenous TSH-binding in functional and proliferative thyroid disorders: Evidence for different membrane characteristics, TSH-receptor capping and TSH-receptor presentation on the inner surface of the follicular epithelium .... 193

Hans-Wilhelm Müller-Gärtner, Claus Schneider, Volker Bay, Angela Tadt and Matthias Jessel 
TSH and biogenic amine signals in the regulation of thyroid function: Independent regulation by protein kinase $\mathrm{C}$ and $\mathrm{G}$ proteins ......... 199

Evelyn F. Grollman, Elisabeth Bone, John Chan, Daniella Corda, Osamu Isozaki, Claudio Marcocci, Pilar Santisteban and Leonard D. Kohn

Stimulation of Graves' thyroids in vitro $\ldots 203$ R. Hörmann, J. Kirner, B. Saller and K. Mann

Immunoreactivity of PTH-binding in intact bovine kidney tissue and cultured cortical kidney cells indicative for specific receptors ...... 207

Axel Niendorf, Hartmut Arps, Manuela Sieck and Manfred Dietel

\section{Thyroid cell growth}

Control of thyroid cell proliferation: The example of the dog thyrocyte ............. 215

S. Reuse, P. Roger, F. Lamy, F. Foureau,

C. Gerard and J. E. Dumont

Polarized properties of thyroid cells: A study with cultured porcine cells ............... 220

Jean Mauchamp, Odile Chabaud, Marianne Chambard, Corinne Gerard, Claude Penel and Bernard Verrier

Paracrine interaction between thyrocytes and fibroblasts ...................... 225

R. Gärtner, G. Bechtner, D. Stübner

and W. Greil

Role of non-TSH factors in thyroid cell growth 231

\section{Margaret C. Eggo, Laura K. Bachrach \\ and Gerard N. Burrow}

Expression of the c-myc proto-oncogene in growth stimulated porcine thyroid follicle cells ..... 238

N.-E. Heldin, F. A. Karlsson

and $B$. Westermark

The FRTL-5 thyroid cell strain as a model for studies on thyroid cell growth .......... 242

Francesco Saverio Ambesi-Impiombato and Giovanni Villone

Role of the adenylate cyclase-cAMP system on TSH-stimulated thyroid cell growth ...... 246

\section{Marcocci, G. F. Fenzi and E. F. Grollman}

Growth factor receptors in thyroid follicle cells 252

K. Westermark, M. Lundquist, G. Hacker,

A. Karlsson and B. Westermark

Evidence that thyroid growth promoting activity of immunoglobulin preparations is due to contamination with EGF . ................. 256

R. Gärtner, C. Tsavella, G. Bechtner and W. Greil

The mechanism of TSH induced increase in binding of EGF to porcine thyroid cell monolayers; the role of thyroid hormones .......... 260

\section{S. Atkinson and P. Kendall-Taylor}

Control of the proliferation and differentiation of GEJ under platelet aggregating factor treatment ........................ 264

Y. Abramovici, N. Boucekkine, J.J. Rémy, J. Salamero and J. Charreire

Inhibition of CAMP formation by EGF in thyroid follicles is mediated by intracellular $\mathrm{Ca}^{++} \ldots 267$

W. Greil, G. Niedernhuber, D. Stübner and R. Gärtner

Stimulation of thyroid cell growth by thyrotropin and epidermal growth factor in isolated porcine thyroid follicles ................... 270

\section{H. Stracke, R. Bär, F. Müller and H. Schatz}

Thyrotropin (TSH) stimulates cell growth and DNA synthesis in monolayer cultures of human thyrocytes independent of the adenylate-cyclase system ...................... 273

Peter E. Goretzki, Rainer Koob, Christine Koller and Hans-Dietrich Röher

Adenylate cyclase stimulation and $\left[{ }^{3} \mathrm{H}\right]$ thymidine incorporation in human thyroid tissues and thyrocyte cultures: The effect of IgG preparation from patients with different thyroid disorders ... 281

Peter E. Goretzki, Michael West, Rainer Koob, Christine Koller, K. Joseph

and Hans-Dietrich Röher

Insulin and insulin-like growth factor-I (IGF-I) regulate differentiation as well as growth in FRTL -5 cells .................. 288

Osamu Isozaki, Pilar Santisteban, John Chan, Evelyn Grollman and Leonard Kohn

Sodium/proton exchange in FRTL-5 thyroid cells: Role in the maintenance of intracellular $\mathrm{pH}$ and TSH-stimulated cell growth ........ 293

C. Marcocci, A. Pinchera and E. F. Grollman 
Workshop on thyroid growth-stimulating immunoglobulins - A report ............. 297

H. Schatz

Autoimmunity and thyroid growth: Methods, concepts and misconceptions ............ 299 J. E. Dumont, P. Roger and M. Ludgate

\section{Clinical aspects of autoantibodies in thyroid diseases and related disorders}

Thyrostatic drugs act through modulation of thyroid cell activity to induce remissions in Graves' disease ......................... 305

Robert Volpé, Anders Karlsson, Rolf Jansson and Per Anders Dahlberg

Effects of high and low doses of methimazole in patients with Graves' thyrotoxicosis 312

G. Benker, D. Reinwein, H. Creutzig, H. Hirche, W. D. Alexander, D. McCruden, G. Galvan, G. Kahály, J. Beyer, J. H. Lazarus, H. Schatz, H. Schleusener, H.-G. Schneider, R. Ziegler, L. Tegler and O. R. Nilson

Do HLA-DR-typing and measurement of TSHreceptor antibodies help in the prediction of the clinical course of Graves' thyrotoxicosis after antithyroid drug treatment? ............ 318

H. Schleusener, J. Schwander, G. Holl,

K. Badenhoop, J. Hensen, R. Finke,

G. Schernthaner, W. R. Mayr and P. Kotulla

On the clinical importance of thyroid microsomal and thyroglobulin antibody determination .. 325

W. A. Scherbaum
The specificity of autoantibodies in Graves' ophthalmopathy $\ldots \ldots \ldots \ldots \ldots \ldots \ldots \ldots \ldots . \ldots \ldots$

P. Kendall-Taylor, D. Jones and S. Atkinson

Pathophysiological and clinical implications of thyroid growth-stimulating immunoglobulins: Evidence for their intrathyroidal production ............................. 334

H. Schatz, I. Ludwig, F. Wiss and P. E. Goretzki

Ciamexon-treatment in endocrine ophthalmopathy ...................... 342

Ch. Utech, K. G. Wulle, P. Pfannenstiel and W. Adam

Graves' autoantibodies to extrathyroidal TSH receptor: Their role in ophthalmopathy and pretibial myxedema .................... 344

C. M. Rotella, F. Alvarez, L. D. Kohn and R. Toccafondi

Sera of patients with idiopathic myxedema contain IgG which block TSH-stimulated thyroid adenylate cyclase ................... 348

P. Vitti, L. Chiovato, A. Lombardi, G. Lopez,

C. Mammoli, F. Santini, G. F. Fenzi and A. Pinchera

Extrathyroidal synthesis and biologic action of thyroid receptor antibody (TRAb) in Graves' disease ....................... 352

R. Paschke, H. G. Heinze, J. Teuber

R. Schmeidl and K. H. Usadel

Evidence of autoimmune pathogenesis in autonomous thyroid adenoma ........... 355

Ch. Sellschopp, M. Derwahl, H. Schaube and H. Hamelmann

Thyroid autoimmunity in 1987: A conclusive remark ...................... 358

G. F. Bottazzo 


\title{
Modulation of class-II antigen expression in human thyroid epithelial cell cultures
}

\author{
B. E. Wenzel ${ }^{1}$, H. Arnholdt ${ }^{2}$, S. Grammerstorf ${ }^{1}$, \\ R. Gutekunst ${ }^{1}$ and P. C. Scriba ${ }^{1}$ \\ Department of Internal Medicine ${ }^{1}$, Institute of Pathology ${ }^{2}$, Medical University, Lübeck, FRG
}

\begin{abstract}
The modulation of HLA-D expression of thyroid epithelial cells (TEC) was studied in vitro by means of immunofluorescence. Under serum-free culture conditions, TSH and TSH-receptor antibodies induce HLA-D on TECs derived from GD-patients. Serum-free culture conditions provide a higher availability of TSH-receptors by a 'right side right' polarity of the cellular morphology. There was no evidence for IFN- $\gamma$ producing cell contaminations on GD-TECs. TSH in contrast to IFN- $\gamma$ does not induce HLA-DQ on TECs. HLA-DQ is not displayed by spontaneously classII antigen expressing GD-TECs. Methimazole as well as perchlorate do not suppress HLA-D expression of TECs.
\end{abstract}

Classically, only immuno-competent cells, namely macrophages or dendritic cells are able to present antigen together with the immuno-regulatory class-II self-antigen (Balfour et al. 1981). These class-II antigens (in man HLA-D locii) can also be found in vivo (Hanafusa et al. 1983) and be induced on thyroid epithelial cells (TEC) by various agents in vitro. In this study we were interested in which potential in vivo regulators of thyroid cell functions could modulate HLA-D expression. We investigated the possibility that there might exist a mechanism to induce HLA-D expression different than the well documented pathway via IFN- $\gamma$ (Todd et al. 1985; Davies et al. 1985; Weetman et al. 1985). Namely, the chronic stimulation of the TSH-receptor and/or the administration of iodine, methimazole, perchlorate, interferon- $\gamma$, TSH-receptor antibodies in TECs grown in culture medium with or without serum supplementation was studied. This aimed at the role that polarity of three dimensional structures play in antigen-presentation in vitro as suggested in vivo (Londei et al. 1984; Wenzel et al. 1986).

\section{Patients}

\section{Materials and Methods}

Thyroid tissue was obtained from patients with Graves' disease (GD) or non-toxic goitre (NTG). GD-patients were iodine loaded for 10 days before surgery. They also had thyroid stimulating antibodies (TSAb), and 6/7 had microsomal (M-antibodies). Patients with NTG were all void of thyroid antibodies.

\section{Thyroid epithelial cells (TECs)}

Thyroid tissue was minced, washed intensively with calcium- and magnesium-free phosphate buffer saline (PBS) and digested enzymatically two times for $1 \mathrm{~h}$ at $37^{\circ} \mathrm{C}$ with $4 \mathrm{mg} / \mathrm{ml}$ collagenase. Cells were then washed twice in PBS containing $10 \%$ foetal calf serum (FCS), separated from erythrocytes and auto-rosettes by density centrifugation, washed again and plated on 8 chamber glass slides $\left(20 \times 10^{4}\right.$ cells/chamber $)$ in Iscove medium. The medium was either supplemented with insulin, hydrocortisone, somastatin, human transferrin and gly-his-lys three peptide in $0.5 \%$ FCS (5H-medium) or with $10 \%$ FCS.

\section{Cell cultures}

TECs were allowed to adhere overnight to the glass slides. After washing with medium, slides were cultured for a further 4 to 5 days with, without, or combinations 
of the following agents: interferon- $\gamma(\mathrm{IFN}-\gamma) 10 \mathrm{U} / \mathrm{ml}$, bovine thyrotropin (bTSH) $1-100 \mathrm{mU} / \mathrm{ml}$ methimazole (MMI) $1-100 \mu \mathrm{M}$; perchlorate (PC) $1-100 \mu \mathrm{M}$; sodium iodide ( $\mathrm{NaI}$ ) $0.1 \mathrm{mM}$; IgG $0.1 \mathrm{mg} / \mathrm{ml}$. In some experiments supernatants from TECs were collected after 2 days and tested on secondary TEC cultures.

\section{Indirect immunofluorescence (IF)}

After pre-incubation TECs were washed and incubated with monoclonal antibodies: Tü 22 - specific for HLADQ; Tü 35 - specific for HLA-DP/DR; Tü 39 specific for HLA-DR/DP; DAKO-DRC1 - specific for T-cells (equivalent to OKT1); DAKO-DR reacting with the $\beta$-chain and DAKO-macrophage $(\varnothing \mathrm{M})$. The $\mathrm{M}$ angigen of thyroid cells was stained with inactivated, diluted patient's sera ( $\alpha-\mathrm{Ml}_{1}: 320^{2}$; negative for $\alpha-\mathrm{Tg}$ ). Rabbit-anti-mouse-IgG ( $\left.\mathrm{F}(\mathrm{ab})_{2}\right)$-FITC and TRITC conjugated rabbit-anti-human IgG were used as second antibodies. IF was assessed with an Olympus photofluorescence-microscope B-H2.

\section{Further procedures}

IgGs were prepared by ion-exchange chromatography. IgGs from GD-patients were TSab and $\alpha-M$ positive, while IgGs from NTG and normals had no autoantibodies as measured by specific ELISAs.

\section{Materials}

Collagenase (Dispase II) was from Boehringer, Mannheim, FRG. Foetal calf serum (FSC), Iscove medium and all cell culture additives were from Biochrom, West-Berlin. Monoclonals, Tü-22/35/39 and interleukin-2 were from Biotest, Dreieich, FRG. FITC and TRITC conjugated second antibodies were from Dakopatt, Hamburg, FRG. Interferon- $\gamma$, Methimazole and all hormone additives were from Sigma Chemie, Munich, FRG. Sodium iodine and potassium perchlorate were from E. Merck, Darmstadt, FRG. Thyrotropin (Thyreostimulin) was from Organon, Munich FRG. Micro-Lab slides (Miles) and sheep erythrocytes were from Flow, Meckenheim, FRG. A BH-2 from Olympus Europe, Hamburg, FRG was used.

\section{Results}

TECs reassociate in cultures into dome-like structures sometime resembling micro-follicles as shown in Fig. 1. Under low serum conditions (5H-medium) the cellular polarity of these structures appears 'right side right'.

In Fig. 2 this particular morphology is demonstrated by nucleii surrounding a lumen with microvilli and filaments of TECs pointing inside. The ability of various agents to induce class-II depends on the source of the TECs, the agent used, and the polarity of cells in cultures. IFN- $\gamma$ induced HLA-DR, but not $\mathrm{M}$-antigen regardless

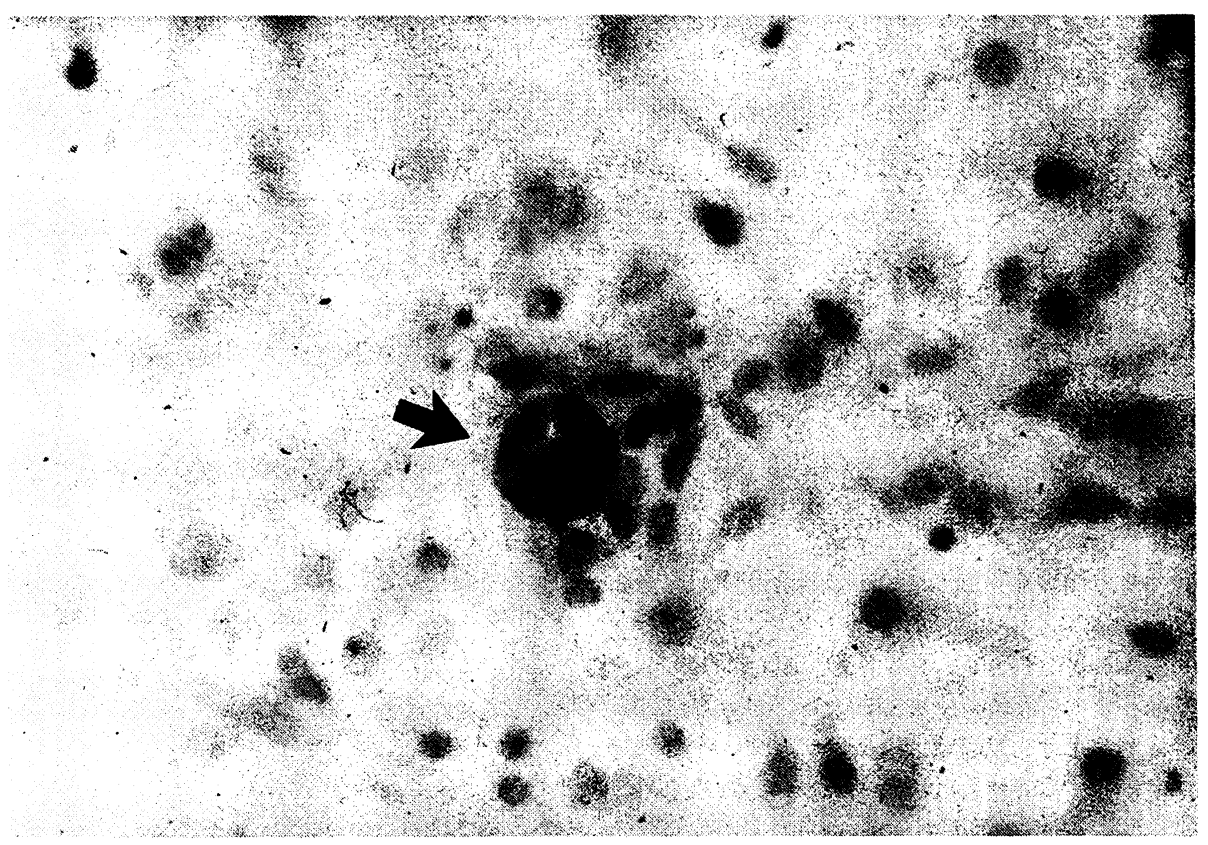

Fig. 1.

Re-association of thyroid epithelial cells under serum-free ( $5 \mathrm{H}$-medium) culture conditions. 

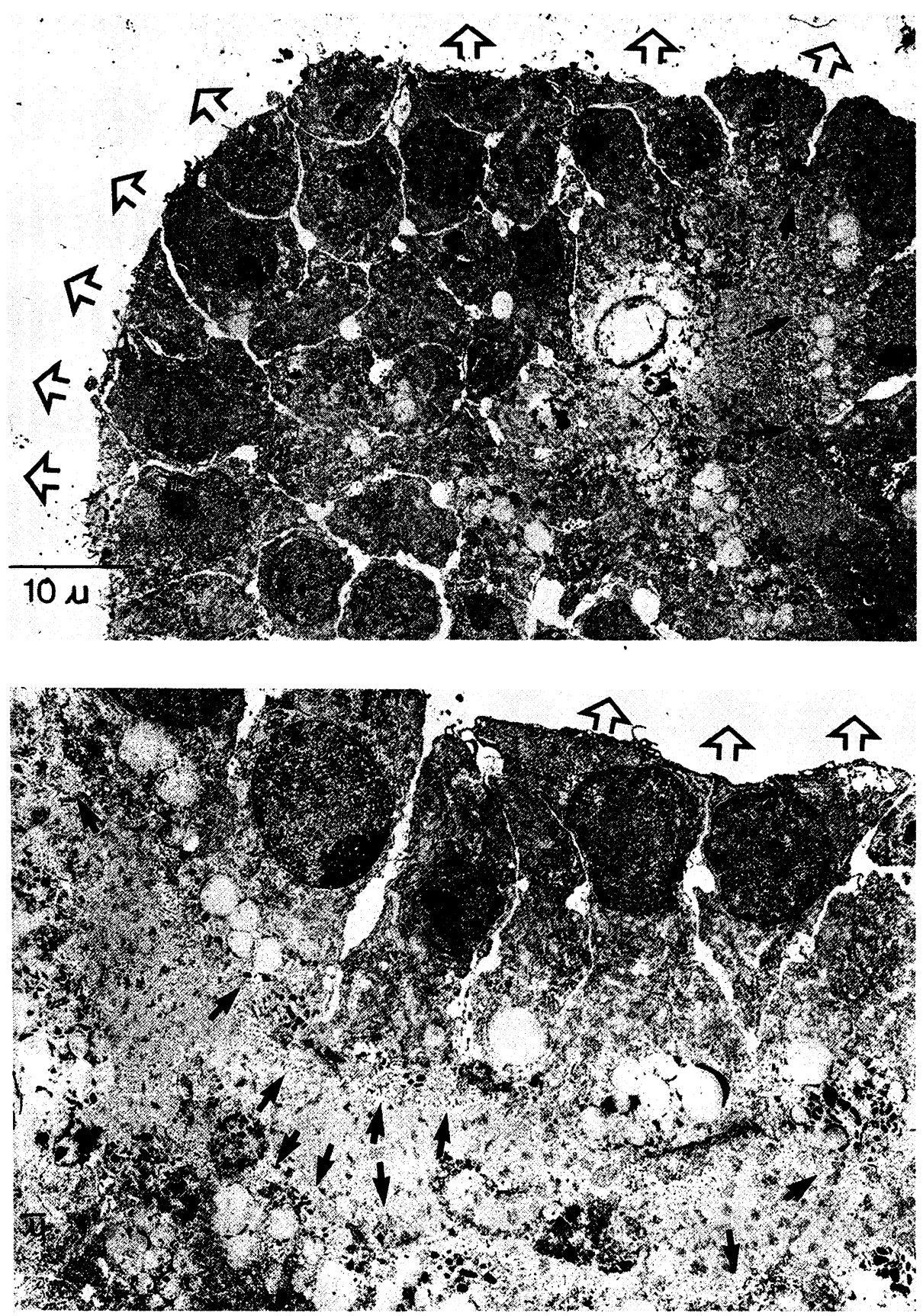

Fig. 2.

Electron-micrograph of follicle-like structures of thyroid epithelial cells grown in $5 \mathrm{H}$-medium. A: Dome-structure; B: Close-up. $\neg$ site pointed to culture medium (outside). $\rightarrow$ microvilli.

of the culture conditions or whether TECs derive from GD-patients or patients with NTG (Table 1).

All agents acting on the TSH-receptor, i.e. TSH and IgG from hyperthyroid GD-patients, induce
M-antigen (Table 1). HLA-DR together with Mantigen is only induced in 5H-medium (Fig. 3; Table 1).

A spontaneous expression of HLA-DR was ob- 
Table 1 .

Expression of HLA-DR and M-antigen by thyroid epithelial cells derived from patients with Graves' disease or with non-toxic goitre.

\begin{tabular}{|c|c|c|c|c|c|c|}
\hline & \multicolumn{4}{|c|}{ Graves' disease } & \multirow{2}{*}{\multicolumn{2}{|c|}{$\begin{array}{c}\text { Non-toxic } \\
\text { goitre } \\
5 \mathrm{H}\end{array}$}} \\
\hline & \multicolumn{2}{|c|}{$5 \mathrm{H}$} & \multicolumn{2}{|c|}{ FCS } & & \\
\hline & DR & M & DR & $\mathbf{M}$ & DR & M \\
\hline IFN- $\gamma$ & +++ & - & +++ & - & +++ & - \\
\hline TSH & ++ & +++ & - & +++ & - & +++ \\
\hline $\operatorname{IgG} *$ & ++ & +++ & - & ++ & - & ++ \\
\hline $\operatorname{IgG}{ }^{N T G}$ & - & - & - & - & - & - \\
\hline $\operatorname{IgG} * *$ & - & - & - & - & - & - \\
\hline
\end{tabular}

* Hyperthyroid GD-patients. ** Euthyroid GD-patients.
Table 2.

Spontaneous expression of HLA-DR by the thyroid epithelial cells derived from hyperthyroid patients with Graves' disease.

\begin{tabular}{l|c|c|c|c}
\hline & $\begin{array}{c}5 \mathrm{H} \\
(1 \text { day })\end{array}$ & $\begin{array}{c}5 \mathrm{H} \\
(5 \text { days })\end{array}$ & $\begin{array}{c}5 \mathrm{H} \\
(5 \text { days }+\mathrm{TSH})\end{array}$ & $\mathrm{SN} *$ \\
\hline HLA-DR & + & - & - & - \\
M-antigen & ++ & - & ++ & - \\
\hline
\end{tabular}

* Supernatant from spontaneously HLA-DR expressing thyroid epithelial cells applied on secondary NTG-cell cultures for 5 days.
A

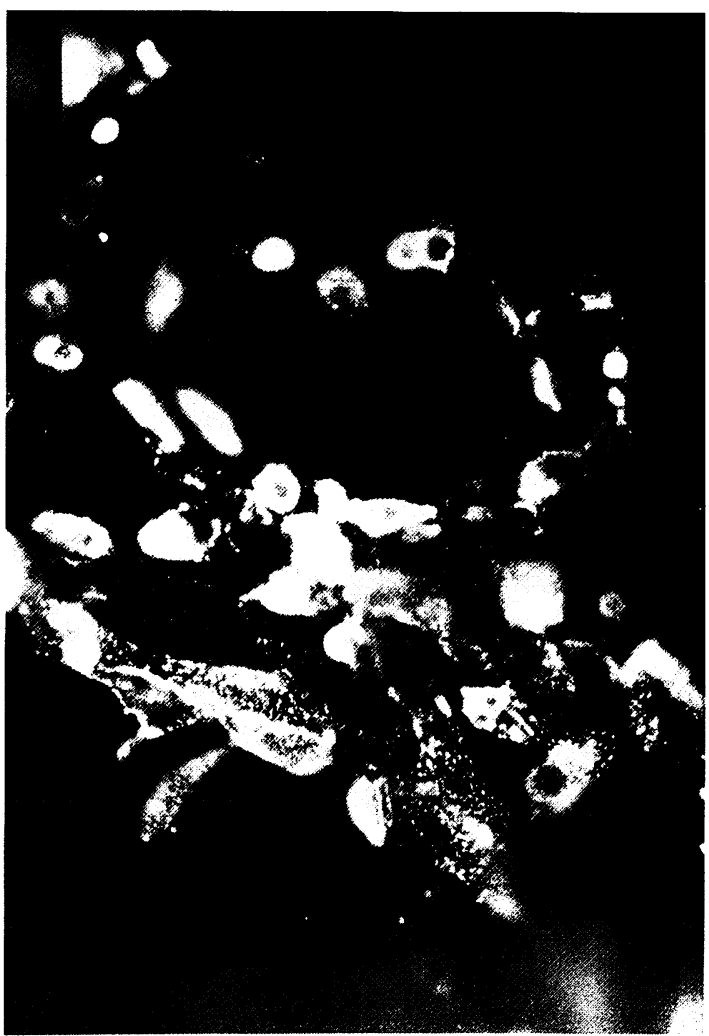

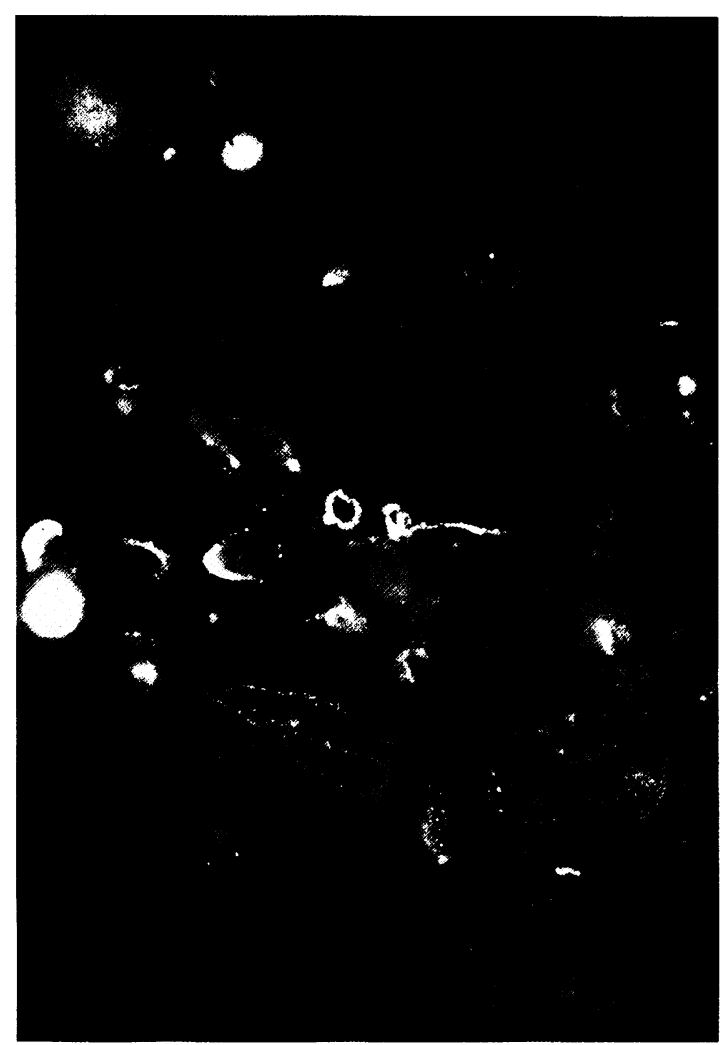

目

Fig. 3.

Expression of HLA-DR and M-antigen by thyroid epithelial cells from patients with Graves' disease. Cells were incubated with $1 \mathrm{mU} / \mathrm{ml} \mathrm{bTSH}$ in $5 \mathrm{H}$-medium for 4 days; magnification approx $\times 450$. A: $\alpha-\mathrm{M}+$ a-hIgG-TRITC. B : $\alpha$-HLA-DR + a-mIgG-FITC. 
Table 3.

Expression of HLA-D polymorphism, lymphocyte-, macrophage-, and dendritic cell antigens by thyroid epithelial cells from Graves' patients.

\begin{tabular}{l|c|c|c|c|c|c}
\hline & DR & DP/DR & DQ & Tl/T2 & $\emptyset \mathrm{M}$ & DRC1 \\
\hline IFN- $\gamma$ & +++ & ++ & +++ & - & - & - \\
TSH & ++ & + & - & - & - & - \\
IgG* & ++ & + & - & - & - & - \\
$5 \mathrm{H}$ (l day) & + & $(+)$ & - & - & - & - \\
\hline
\end{tabular}

* Cells grown in $5 \mathrm{H}$-medium.

served in some TEC-cultures derived from GDpatients (Table 2). This disappeared after 5 days in culture. But HLA-DR expression could be re-induced with TSH. Supernatants (SN) of these particular TEC-cultures could not induce class-II expression, when applied on secondary TEC-cultures. When the HLA-D polymorphism of class-II expressing TECs was assessed, different staining patterns were observed with different inducing agents. While TSH, IgG-GD* induced, and spontaneously expressing TECs never displayed HLADQ, a bright stain of HLA-DQ was found after IFN- $\gamma$ incubation (Table 3).

TEC-cultures were investigated by means of IF with specific monoclonal antibodies for contaminations with dendritic cells, macrophages or $\mathrm{T}$ cells. Only in cultures with FCS could a weak staining of scattered macrophages sometimes be observed. When the effect of MMI or PC on IFN- $\gamma$ or TSH induced HLA-D expression was investigated, only a slight decrease of HLA-D staining could be observed (Table 4).

\section{Discussion}

Admittedly, these in vitro studies can only give limited information about the induction of class-
II expression by TECs in vivo. Our studies suggest, however, that the chronic stimulation of TECs through the TSH-receptor as well as the cellular polarity of TECs play a role in the modulation of class-II expression. We postulate that the cellular polarity modulates the availability of TSH-receptors in TEC-cultures (Mauchamp et al. 1979). This appears to be the reason, why the induction and reexpression of class-II antigen by TSH could only be observed under serum free culture conditions. The class-II expression of TECs in vivo (Londei et al. 1984) resembles more generally the staining pattern we observed after induction with $\mathrm{TSH}$ than that with IFN- $\gamma$. In contrast to TEC-cultures expressing spontaneously HLA-DR and M-antigen, IFN- $\gamma$ strongly induces HLA-DQ, and can induce in vitro TECs derived from autoimmune (GD) as well as nonimmune (NTG) thyroid patients. Moreover, we could not detect by means of indirect IF contaminating dendritic cells, T-cells or macrophages which would account for IFN- $\gamma$ production in our serum free culture system. In addition to that, the supernatants of spontaneously class-II expressing TEC-cultures could not induce class-II in secondary TECs, which one would expect if IFN- $\gamma$ would be produced by contaminating activated lymphocytes in TECs. On the other hand, we could also

Table 4.

Effect of methimazole (MMI) and perchlorate (PC) on the HLA-DR of thyroid epithelial cells.

\begin{tabular}{l|c|c|c|c|c|c|c}
\hline & IFN- $\gamma$ & + MMI & + PC & + TSH & TSH & + MMI \\
\hline DR & +++ & +++ & ++ & +++ & ++ & ++ \\
DQ & +++ & ++ & ++ & +++ & - & - \\
\hline
\end{tabular}


not detect interleukin-1 in these supernatants (not shown).

The effect MMI has during suppression therapy of GD in vivo and on antibody synthesis in vitro (McGregor et al. 1980) has been attributed to immuno-suppressive effects. In our hands, MMI and PC have no effect on class-II expression of TECs. This reflects previous findings in recurrent hyperthyroidism of GD-patients (Carel et al. 1986) and findings in GD-therapy where MMI had the same effect as PC, which surely is not considered as an immuno-suppressive drug (Wenzel et al. 1984).

\section{Acknowledgments}

The expert technical assistance of Ms A. Bulasch is gratefully appreciated.

This project was supported by Deutsche Forschungsgemeinschaft SFB 232/C 4 .

\section{References}

Balfour B M, Drexhage H A, Kamperdijk E W A \& Hoefsmit E C M (1981): Antigen-presenting cells, including Langerhans' cells, veiled cells and interdigitation cells; in microenvironments in haemopoietic and lymphoid differentiations. Ciba Symp 84: 281.

Carel J C, Rémy J J, Zuchman D, Salamero J \& Charreire J (1986): Role of methimazole on DR antigen expression on human thyroid epithelial cell cultures. In: Drexhage H A \& Wiersinga W M (eds). Thyroid and Autoimmunity, pp 145-147. Excerpta Medica, Elsevier, Amsterdam.
Davies T F (1985): Co-cultures of human thyroid monolayers and autologous T cells-impact of HLA class II antigen expression. J Clin Endocrinol Metab 61: 418-422.

Hanafusa T, Pujol-Borrell R, Chiovato L, Russel R C G, Doniach D \& Bottazzo G F (1983): Aberrant expression of HLA-DR antigen on thyrocytes in Graves disease: relevance for auto-immunity. Lancet 2: 1111 .

Londei M, Lamb J R, Bottazzo G F \& Feldmann M (1984): Epithelial cells expressing aberrant MHC class-II determinations can present antigen to cloned human T-cell. Nature 22: 639 .

Mauchamp J, Margotat A, Chambard M, Charrier B, Remy L \& Michel-Bechet M (1979): Polarity of threedimentional structures derived from isolated dog thyroid cells in primary culture. Cell Tissue Res 204: 417-430.

McGregor A M, Petersen M M, McLachlan S M, Rocke P, Smith S R \& Hall R (1980): Carbimazole and the autoimmune response in Graves' disease. N Engl J Med 303: 302.

Todd I, Pujol-Borrell R, Hammond L J, Bottazzo G F \& Feldmann M (1985): Interferon- $\gamma$ induces HLA-DR expression by thyroid epithelium. Clin Exp Immunol 61: 265-273.

Weetman A P, Volkman D J, Burman K D, Gerrald T L \& Fauci A S (1985): The in vitro regulation of human thyrocyte HLA-DR antigen expression. J Clin Endocrinol Metab 61: 817-824.

Wenzel B E, Gutekunst R, Mansky T, Schultek Th \& Scriba P C (1986): Thyrotropin and IgG from patients with Graves' disease induce class-II antigen on human thyroid cells. In: Drexhage $\mathrm{H}$ A \& Wiersinga W M (eds). Thyroid and Autoimmunity, pp 141-144. Excerpta Medica, Elsevier, Amsterdam.

Wenzel K W \& Lente J R (1984): Similar effects of thionamide drugs and perchlorate on thyroid-stimulating immunoglobulins in Graves' disease: evidence against an immunosuppressive action of thionamide drugs. J Clin Endocrinol Metab 58: 62. 